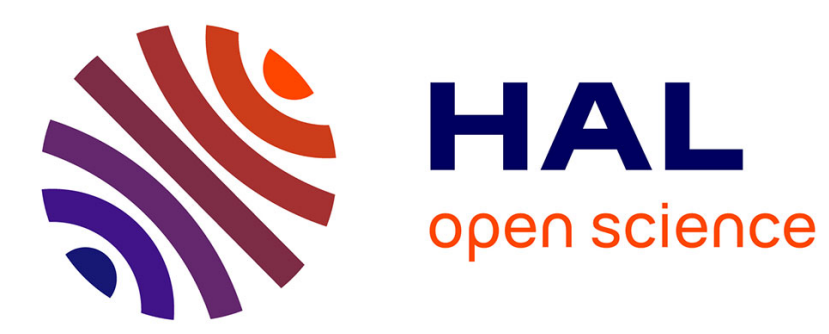

\title{
Competition Policy and Innovation
}

David Encaoua, Abraham Hollander

\section{- To cite this version:}

David Encaoua, Abraham Hollander. Competition Policy and Innovation. Oxford Review of Economic Policy, 2002, 18 (1), pp.63-79. 10.1093/oxrep/18.1.63 . halshs-00185360

\section{HAL Id: halshs-00185360 \\ https://shs.hal.science/halshs-00185360}

Submitted on 5 Nov 2007

HAL is a multi-disciplinary open access archive for the deposit and dissemination of scientific research documents, whether they are published or not. The documents may come from teaching and research institutions in France or abroad, or from public or private research centers.
L'archive ouverte pluridisciplinaire HAL, est destinée au dépôt et à la diffusion de documents scientifiques de niveau recherche, publiés ou non, émanant des établissements d'enseignement et de recherche français ou étrangers, des laboratoires publics ou privés. 


\title{
COMPETITION POLICY AND INNOVATION
}

\author{
David Encaoua (Université de Paris I Panthéon-Sorbonne, \\ EUREQua) \\ and \\ Abraham Hollander (Université de Montreal, Centre de \\ Recherche sur les Transports)
}

\author{
Revised version ${ }^{1}$ \\ January 2002
}

\begin{abstract}
:
The question addressed by the paper is whether standard procedures and widely accepted insights of competition policy remain valid when one deals with potentially anti-competitive conduct in innovative industries. The question of appropriateness arises because competition in these industries displays features that are radically different from those encountered in traditional sectors of the economy. Competition is for the market rather than in the market, dynamic aspects of competition matter more than allocative aspects, intellectual property rights (IPR) reinforce network effects present in knowledge-based industries. The paper examines why these differences matter with respect to market delineation, assessment of intensity of competition and, predatory conduct. It also raises the question to what extent competition law limits the innovator's rights not to license them to others, especially when they correspond to essential facilities. It explores the problem created by excessive protection as well as the hold-up problem that arises in a context of sequential innovations. It examines the antitrust position in regard to the treatment of collaborative arrangements among holders of IPR's, such as cross-licenses, patent-pools and joint standard settings. Finally, it presents a discussion on a possible role of competition law in shaping intellectual property laws in order to benefit from the complementarity's between intellectual protection and antitrust rules.
\end{abstract}

Key words: antitrust, intellectual property right, cumulative innovation, crosslicenses, patent-pools, joint standard setting.

JEL classification: L40, O33, O34

\footnotetext{
${ }^{1}$ The authors thank Christopher Budd, Claude Crampes, Dominique Guellec and David Ulph for their useful suggestions and comments to a previous version of this paper.
} 


\section{Introduction}

This paper examines issues that revolve around the enforcement of competition law in innovative industries. Firms in innovative industries are engaged in activities rich in technological opportunity. For that reason, they are expected to generate a sustained flow of new products and processes, some of which may represent major rather than incremental advances. Competition in innovative industries displays features not encountered in traditional sectors of the economy - sectors that have shaped accepted wisdom in regard to antitrust enforcement procedures. This raises the question whether these procedures are applicable to highly innovative industries.

In the main, the objective of antitrust, or competition policy, is to enhance, economic welfare. Competition policy pursues this objective by quelling forms of conduct that reduce the number of market participants or their ability to compete. The aim is to avoid conditions where an individual agent or group of firms acting jointly become immune from the disciplining influence of rivalry. Competition policy posits that rivalry in the marketplace prompts firms to reduce waste and offer at the lowest possible price a range of products closely tailored to consumers' preferences.

The problem is that in highly innovative industries, the effects of competition on each of the aforementioned components of economic performance do not necessarily match those found in mature industries. This explains why the ongoing debate about the validity of antitrust procedures in innovative industries is so controversial ${ }^{2}$. Of major importance in this regard - particularly for industries with high technological opportunity - is the question how the intensity of competition affects the rate if innovation.

The objective of this paper is not to provide detailed economic analysis of the relationship between competition and innovation or to supply a detailed assessment of the antitrust jurisprudence. It is to give an overview of salient issues and to highlight the pitfalls of a mechanical application to high tech sectors of methods developed with mature industries in mind. More generally, the paper explores three different channels whereby competition policy in innovative industries is liable to affect welfare. They correspond respectively to competition in the innovation race (competition for the market), competition in the technology market (through diffusion of knowledge, licensing and other forms of technology transfer) and competition in the product market. The intensity of rivalry in each of these markets has an impact on technological progress via incentives to innovate. At the same time, innovation affects competition via it effects on industry structure.

The paper focuses on three issues. First, it provides some theoretical analysis of how competition affects the pace of innovation and how innovation affects the evolution of market structure. Second, it examines the risks of applying an approach inspired by a static view of markets to a setting where structure is at all times evolving as a result of the introduction of new technologies. Third, it explores the relationships between

\footnotetext{
2 The main arguments that bear on the ongoing debate can be found in Posner (2001), Audretsch et. al. (2001), Eisenach and Lenard (1999), Bresnahan (1999), Katz and Shapiro (1999), Rubinfeld (1998)).
} 
competition policy and intellectual property rights. In regard of the latter, it asks whether the two bodies of law are necessarily in conflict. It also touches upon the question whether the recent extension of patent protection to new areas is likely to increase the rate of technological innovation. Furthermore, it examines the position of antitrust authorities vis-à-vis some forms of cooperation between innovative firms.

The paper is organized as follows. Section 1 discusses specific characteristics of competition in innovative industries. It also delves into the theoretical foundations of the effects of product market competition on incentives to innovate and derives implications for competition policy. Section 2 concentrates on the shortcomings of standard antitrust enforcement procedures in innovative industries. It identifies problems raised by a static approach of competition policy in regard to market delineation, the appraisal of competition and, the assessment of market power. Predatory pricing is used to exemplify how the standard procedures may mislead in a highly innovative environment. Section 3 explores potential and real conflicts between intellectual property law and competition law. It asks to what extent competition law may restrict an innovator's right not to use his protected knowledge and not to license it to others. Section 4 deals with the problems raised by cumulative and complementary innovations. It argues that strengthening intellectual property rights may slow the speed of technical progress. It also examines the attitude of antitrust authorities with respect to cross-licensing, patent-pooling and joint standard setting. The concluding section reflects on a possible role for competition authorities in shaping intellectual property law.

\section{Competition in innovative industries}

\section{i/ Competition in the market versus competition for the market}

Competition in innovative industries is best pictured as a sequence of races to develop new technologies. Victory in a race is often followed by the attainment of a leadership position in one or more product markets. This, however, does not entail that the winner can rest and quietly enjoy the fruits of victory. Maintaining leadership almost invariably requires the immediate entering of a new race. For that reason, a string of successive wins by the same firm, accompanied by persistent leadership in a product market, does not carry the implication that competition is necessarily absent. Technological opportunity and winner-take-all (or winner-take-most) outcomes suggest that the form of competition that matters most from a welfare point of view is not that which takes place in a product market as is the case for mature industries. It is competition for the product market, i.e. a race to be the first to bring a new product to market or to produce by means of a new technology. In contrast to mature industries where new participants gradually acquire market share, successful entry in innovative industries often results in a rapid replacement of the dominant incumbent.

Because the $R \& D$ cost in these industries is substantial and largely independent of production volumes, average total cost declines with output. The implication is that firms cannot survive by setting price close to marginal production cost.

Also, network effects as well as positive feedback effects are common in knowledgebased industries. Network effects refer to the increase in value each user attributes to 
a product when the number of other users increases, as in the case of fax machines for instance. There is positive feedback when goods are complementary and increased use of one good makes the other goods more valuable to users. For instance, a larger installed base of an operating system enhances the value of word processing software that runs on that system. Similarly, increased use of that software enhances the value of the operating system. Both network and positive feedback effects generate intertemporal increasing returns to scale. Markets were these effects are strong are subject to "tipping" i.e. there is a point in time when the existence of different incompatible products may become unstable. The consequence is dominance by a single product. Tipping contributes to adoption of a de facto standard.

What also matters from a competition policy perspective is that the knowledge produced by innovators can be exploited either directly by having innovators themselves produce and sell goods and services that embody the newly created knowledge or, indirectly, via a transfer of new knowledge by licensing it to others who undertake production.

Therefore, competition policy in innovative industries is liable to affect welfare through three distinct channels. First is the intensity of the race to innovate. Second is competition in the product market, presumably affecting variables such as price and service quality. The third channel is competition in the licensing market. Conduct that lessens competition in one area may strengthen it in another. As a result, competition policy inevitably confronts two intertwined but conceptually different issues: i) how to assess the effects on competition in each of the three aforementioned areas; ii) how to calibrate trade-off between possibly contrary effects of competition in different areas; specifically, how to assigns weights to dynamic and static aspects of competition.

These characteristics of rivalry in innovative industries are relevant to the question how one judges the effectiveness of competition policy. If one takes the view that competition policy is more naturally oriented towards the aspects of competition in the product market, the effectiveness of competition policy in innovative industries depends on whether more intense competition in the product market increases dynamic efficiency. In other words, if races to bring new products to market or to reduce costs are critical, and if one expects winners to gain all or the lion's share of the market, then competition policy must be judged on the basis of whether it increases the incentives to innovate.

\section{ii/ The relation between product market competition and the incentives to innovate: a theoretical overview}

In their pioneering work, Arrow (1962), Lee and Wilde (1980), Dagupta and Stiglitz (1980) have looked at the question how changes in the number of participants in an $R \& D$ race affected the rate of innovation. On the basis of their findings others have claimed that more intense rivalry always increases incentives to innovate. This is not quite true. The problem is that this claim does not explicitly distinguish between the number of participants in an innovation race and competition in a product market. An increase in the number of racers always increases $R \& D$ effort. The more relevant question from a public policy point of view is how competition in the product market affects the rate of innovation. 
In order to properly address this question, one must use a framework that has the following features 1) the intensity of competition in the product market should be defined in terms that are both precise and sufficiently general; 2) product market structure at each point in time should be endogenously determined by the distribution of costs across firms and by the intensity of competition; 3) analysis should bear both on industries where firms have similar costs (leveled industries) and, industries where cost differ substantially across firms (unleveled industries $)^{3}$.

Recent results by Boone (2001) provide some interesting insights. First, intensity of competition is defined is general terms. An increase of competition in a leveled industry lowers each firm's profit ("level effect"). An increase of competition in an unleveled industry reduces the profit of the least efficient firm. It increases the profit of the most efficient firm provided competition is intense The latter results are labeled "variance effect". Also, as the technological gap between the most efficient firm and the least efficient firm increases, stronger competitive pressure lowers the number of active firms in the market.

Boone assumes that the $\mathrm{R} \& \mathrm{D}$ sector consists of a number of laboratories that engage in race, the prize of which is an infinitely lived patent on a cost-reducing technology. The winner sells the patent to the highest bidder among firms in the industry. Boone finds that the identity of the winner depends on the intensity of competition. When intensity is low, a less efficient firm has greater incentive to buy the innovation than a more efficient one. When it is high, a more efficient firm has the greater incentive to innovate. These results are generalizations of earlier findings by Vickers (1986) and Beath et al. (1995), who show that in Bertrand competition, low cost firms innovate while in Cournot competition, high cost firms can be the innovators.

The intuition is clear: The sacrifice in profit by a technological leader who fails to innovate increases with the intensity of product market competition. The implication is that ones observation that process innovations come from a technological leader rather than from other firms should be interpreted as a signal of its higher efficiency rather than of the absence of rivalry in the product market. Similarly, a process innovation introduced by some inefficient firm or by a new entrant is indicative of the fact that strategic considerations do not matter too much in the market.

The second step in Boone's (2001) analysis involves an investigation of the link between the intensity of competition and the incentive to innovate where the latter is measured by the winner's willingness to pay. The main result is that this relationship is not always monotonic. This is due to the fact that changing the intensity of competition changes the identity of the winner and consequently the valuation of the innovation. More precisely, when the cost improvement is substantial, an increase of the competitive pressure increases the valuation of the innovation. When the improvement in cost reduction is minor and competition in the product market is weak, increasing competition has an ambiguous effect on the willingness to pay the innovation. It may be positive or negative. Overall, one cannot be sure that more intense product market competition always leads to faster technological progress.

\footnotetext{
${ }^{3}$ The latter is necessary because innovation affects the dynamics of industry structure.
} 
Two implications for competition policy are important. First, increased dominance by a single firm must not be interpreted as a lack of competition. Rather, it may signal that the technological leader has the most incentive to innovate because competitive pressure is strong.. Second, competition policy could increase the speed of technological progress in the economy by making a distinction between innovative industries: 1/ In industries where innovation leads to a small cost reduction and where the level of competition is weak, it would be better to aim for low intensity competition. This would give a follower an incentive to leapfrog a technological leader. In such industries, turnover among the leading firms is high. 2/ In industries where innovation leads to a major cost reduction and where competition is intense, increasing the level of competitive pressure is the appropriate policy. Moreover, in such industries, one is likely to observe a persistent dominance by a single firm. Absence of leapfrogging should not be viewed as indicative of little competition.

Boone's results have been obtained in a framework involving a single race in which the process innovation is deterministic. Encaoua and Ulph (2000) have used a model that assumes successive innovations taking place at different points in time according to a Poisson law, with a hazard rate depending on R\&D effort. There is a continuum of industries in the economy, with two firms in each industry. When, in some industry, a technological laggard is successful in innovating, two possibilities must be considered: When there is little diffusion of knowledge in the industry, a laggard firm is able to innovate only from its own technological base and, when it does, it catches up with the leader. This matches the "step by step" process of innovation as in Aghion et al. (1997, 2001). But, when there is a speedy diffusion, a laggard firm may innovate from the current knowledge frontier and, if successful, leapfrogs the leader. This is close to the "creative destruction" assumption in endogenous growth theory (Aghion and Howitt, 1992, Caballero and Jaffe, 1993). It appears that the effects of product market competition on innovation and growth depend on the value of a knowledge diffusion parameter. When it is sufficiently high, an increase in competitive pressure always increases the speed of technologic al progress because the follower has a higher incentive to innovate. This corresponds to the "escape from competition effect". When the diffusion is low, the effect of competition on innovation and growth may become negative. An increase in competitive pressure lowers the R\&D effort of a follower and reduces the proportion of "leveled" industries at equilibrium. In other words, the "level effect" outweighs the "variance effect" in this case.

One implication of these results is that the degree of knowledge diffusion is crucial to obtain a positive impact of product market competition on the pace of innovation. This diffusion depends on the patent holders willingness to transfer their knowledge by licensing their patents or, by using any other contractual form of transfer. Increasing the diffusion by giving to the patent holders incentives to license their patents may thus become an important objective.

\section{Antitrust enforcement in innovative industries}

\section{i/ Market delineation and the appraisal of competition.}


The standard antitrust analysis involves a stepwise procedure. It starts with the delineation of one or several markets where competition may be affected. It then proceeds with the assessment of the state of competition and of the effects of the impugned conduct in the market. If the conduct is found to have lessened competition substantially or is expected to do so, there may come a third step involving a comparative analysis of the effects of various remedies.

\section{Market delineation}

Market delineation is an analytical tool that helps determine whether a firm or a group of firms can act freely from the influence of others in areas where such action matters most in regard to consumer welfare. ${ }^{4}$ Market delineation typically starts with a product (or a collection of products) currently produced and proceeds by asking the following questions: i) How would the profits of the current seller(s) of the product be affected if its price underwent a change; ii) which products do consumers perceive to be substitutes to those produced by a seller at the current price and, which would they perceive as such if the same seller priced close to production cost. The first question is more likely to be raised in a merger case, the second in an abuse of dominance suit.

This approach raises two difficulties in a context where competition centers on innovation. The first problem flows from the choice of an existing product as a starting point of a process that delineates a market by adding producers sequentially until a predetermined stopping rule applies. The second derives from the use of hypothetical price changes to separate the producers belonging to the market from the outsiders.

In non-innovative industries the standard approach which considers hypothetical price changes makes sense because concern is with monopoly pricing in a product market ${ }^{5}$. When dealing with an industry where the pace of innovation is key, antitrust markets ought to be defined in a way that makes them useful in assessing firms' liberty to choose R\&D expenditure unconstrained by others. It is not obvious that this can be accomplished by searching for substitution possibilities among existing products. In innovation races, the focus has to be on future products (Audretsch et al. 2001).

In this regard though, one must keep in mind that firms searching for new ways to satisfy a particular consumer need not at present sell close substitutes. One must also consider the possibility that firms currently in the same product market may devote their R\&D effort to next-generation products that are not close substitutes.

Market delineation in innovative industries must be based on the degree of overlap between the next-generation products perceived at present to emerge from the R\&D efforts of different firms. In this regard one must also take into account that a single $R \& D$ program might profit several next-generation products that are not substitutes of

\footnotetext{
${ }^{4}$ How one goes about defining the relevant market must therefore depend on the nature of the action that matters from a competition perspective. The recent Microsoft case is revealing in this regard. Although the focus centred on the pricing and tying of the browser, the litigious conduct was designed to protect market power in the market for operating systems.

${ }^{5}$ Even when such variables as quality and variety are important instruments of competition one tends to posit that they change in a way that affects consumers in the same way as the expected or observed price changes.
} 
each other. Clearly, decisions in regard to $R \& D$ spending depend on the expected returns from all applications. Such knowledge cannot be expected to rest within antitrust enforcers. Thorough consultation with industry must therefore be part of the market definition process in innovative industries.

\section{Assessing market power}

A firm may enjoy a large market share either because it faces no competition or because it is more efficient than its competitors. In both cases, profitability is regarded as an element belonging to the bundle of indicators of market power. But, in markets driven by innovation, high ex-post returns on investment do not reveal anything about market power. Indeed, if such returns were unachievable, no one would take part in the race. The relevant criterion is expected return. This datum, however, is not easily calculable or straightforward to interpret. It is true of course that in mature industries as well, expected earnings rather past earnings are what matters. However, in the latter industries it is far more likely that the assets that made it possible to obtain these earnings in the past will not suddenly and thoroughly become obsolete in the near future. Therefore, looking backwards in order to gain an appreciation of future profits including profits from monopoly power is more revealing in a mature industry than in an innovative industry. When dealing with the latter one must also be careful to insure that the inferences about monopoly power drawn from profitability measures are adjusted for risk.

Furthermore, at the industry level, profitability measures may be biased upward by ignoring past investment by firms that no longer exist or biased downward by incorporation of investment made by successful innovators who have not yet had the chance to bring a product to market.

\section{Entry}

In traditional industries, monopoly power requires more than the mere absence of significant competitors in the market. It also requires that firms not currently in the market not be able to enter in within a short time at a sufficient scale. The scale of entry whose likelihood needs to be assessed is the scale necessary to discipline actors already in the market. In humdrum industries the area of concern is generally price and the required entry scale is therefore that which eliminates independent pricing. It is not a scale that normally requires that a single entrant or a collection of entrants gain the lion's share of the market.

In innovative industries by contrast entry into a product market can be profitable only if it is expected to lead, within a reasonably short time, to the acquisition of considerable market share in the product market. The question is therefore whether all the assets required to achieve such entry are available outside the firm currently dominant in the product market. Practically, that means that an outsider must possess superior technological know-how not yet exploited in the relevant product market. Complementary assets in production and distribution must also be available outside the dominant firm. However, these assets need not be controlled by the same entity as the knowledge assets. Licensing of knowledge and other arrangement make it possible to enter without being the owner of all the needed inputs. However, in view of the fact 
that both licensing and the transfer of knowledge entail cost, entry is more likely when all necessary complementary inputs are owned by the same entity.

Barriers to entry are high when the amount of resources a firm puts at risk by entering are high compared to expected profit. In this regard, it is important to keep in mind that the amount of money put at risk is probably less than proportional to the scale of entry because most of the costs that have sunk components are fixed.

\section{ii/ Conduct: Predation and other exclusionary strategies}

Exclusionary as well as competitive conducts frequently eliminate rivals. Competitive conduct produces exit when a firm can no longer keep up with the efforts of other firms to offer improved products or lower prices. The distinguishing feature of exclusionary conduct is that it takes aim deliberately at rivals or potential rivals in an effort to inhibit their capacity to compete. The payoff from such conduct is expected to flow not from increased consumer satisfaction but from reduced competition.

Testing for predation requires that one establish a baseline against which initial sacrifices and subsequent extra profits are assessed. In a world of perfect information, it would be sensible to let that baseline be the level of profit under some (optimal) non-exclusionary conduct. In the real world, this is not practical because to infer the potential profits from such hypothetical conduct calls for unobtainable information about current and future cost and demand structures. It also puts the burden on courts to form opinions about the consequences of hypothetical business strategies.

Feasible alternative inferences of predatory intent can be obtained through testimony or, from deductions grounded on simple tests. Under the Areeda and Turner (1975) criterion, a price at or above the reasonable anticipated average variable cost - a proxy for marginal cost - is conclusively be presumed lawful, whereas a price below such cost is conclusively presumed unlawful. ${ }^{6}$ The predatory standard in the US as determined by the Supreme Court in the Brooke case is that below-cost pricing is necessary for a finding of predation. ${ }^{7}$

While such test of predatory pricing has its shortcoming in traditional industries, it is basically a non-starter in highly innovative industries, particularly those where network effects and positive feedback are srong. In such industries competitive pricing looks very much like predatory pricing in traditional industries. Low initial prices help a firm to quickly expand its customer base thereby putting it in a position where it can start charging higher prices because its product has become more valuable. A firm exempt from any competitive threat may also find it advantageous to adopt such penetration pricing strategy. However, competition for the market is likely to strengthen the incentive to quickly attain significant size and market share, possibly in order to have ones standard adopted by the industry.

\footnotetext{
${ }^{6}$ This rule was used to absolve IBM of predatory price-cutting. California Computer products Inc et al. v. International Business Machines, 613 F. 2d 727, $9^{\text {th }}$ cir. 1979

${ }^{7}$ The court also held that plaintiffs have to establish that the predator had a reasonable expectation of recouping the initial losses through future price increases. [Brooke Group Ltd.v. Brown and Williamson Tobacco Corp.,U.S. 209, 113 S.Ct. 2578;125 L.Ed. 2d 168 (1993)]
} 
Because winner-take-all implies loser-take-nothing, price strategies designed to avoid eviction do, in the main, overlap those designed to evict others. In markets that possess the characteristics described above, the prize is obtained by becoming dominant or maintaining a position of dominance in the product market. Therefore any battle in the product market - including a price battle - to gain or maintain that position must be viewed as an investment in future returns. In this regard it is not different from the race to innovate. It is pointless to ask whether an impugned policy would be profitable if it did not bring about a rival's exit. As long as there is intense competition in the product market, the answer, almost surely, is that it would not.

The relevant question in regard to exclusionary conduct is whether, in the race to acquire market share, firms make the effort to run faster than rivals or whether their effort is directed at slowing rivals. In this regard, it is interesting to consider the possibility of predatory product innovation. The latter involves the launch of a new product that competes with an existing product already marketed by a rival. The objective is to reduce rival's sales and evict him from the market. ${ }^{8}$ What makes the launch predatory is a lack of expectation that the new product would generate a positive return.

However, if competition for that new product is competition for the market, then the absence of positive returns can only mean that the revenue from the sale of the new product does not permit recovery development and production costs even if the rival exits. But, if so, predatory product introduction can be rational only if it helps protect other products sold by the predator from encroachment by the target firm. Necessary conditions for predation are therefore: 1) expected lifetime revenue from sales of the new product is less than incremental development and production cost; 2) expected increment in sales from all products is larger than the incremental development and production cost of the new product. However, failure to meet one or both of these tests after the facts does not imply the absence of predatory intent; it may reflect erroneous expectations. What matters in regard to predatory intent are the expectations at the time R\&D cost and other set-up cost are sunk. Thereafter, the reversible cost is likely to be less than price even if the latter does not allow recovery of all costs.

In regard to $R \& D$ it is important as well to consider that spillover effects may affect the conclusions one can draw from cost versus revenue comparisons. When the R\&D required to launch product $B$ has beneficial effects on the cost of producing an older product $\mathrm{A}$ or, if it improves the attractiveness of that product to consumers, then this should be netted. Indeed, it is a benefit that does not flow from an increase of market power in product $\mathrm{A}$.

Fortunately, a product launch is likely to be backed up by internal documents that may provide direct evidence of intent that cannot be garnered from cost versus revenue comparisons. The case against IBM where the company was accused of having introduced a supercomputer as part of a predatory strategy targeted at Control

\footnotetext{
${ }^{8}$ Ordover and Willig (1981, page 22) put forward that "product innovation may be more effective than price-cutting in inducing exit of a rival because the associated costs to the firm are largely fixed and irreversible. After a firm commits the requisite R\&D and other fixed costs, the remaining reversible cost of the product introduction may be so small that the firm would not abandon its tactic whatever the rival's response. Aware of this fact, rivals may quickly exit".
} 
data is a case in point ${ }^{9}$. Much the evidence entered in court revolved around the question whether IBM anticipated losses from its super computer. An alternative theory, one supported by internal documents, was that IBM engaged in product market signaling. According to that theory, it made sense to purchasers of generat purpose computers who confronted uncertainty concerning product quality to emulate the purchasing behaviour of the better-informed buyers of scientific computers. If so, introduction by IBM of a product that the well-informed would purchase allowed the company to perform a useful signaling function (Pittman, 1984).

\section{Antitrust and the protection of intellectual property: complementary or conflicting?}

How do the antitrust laws link up with the intellectual property (IP) laws? At a high level of abstraction, the two bodies of laws appear complementary. Both pursue a welfare objective. IP laws do so by creating and protecting the right of innovators to exclude others from using their ideas or forms of expression This provides economic agents with the incentive to engage in efforts that produce technological innovations and new forms of artistic expression. Patent law encourages the diffusion of knowledge by making the grant of a patent conditional on the disclosure of essential characteristics of the innovation for which a patent is sought. This facilitates access by other innovators to the knowledge embodied in the patent. A further incentive to diffusion is provided by provisions that make it possible to exploit intellectual assets via licensing arrangements. In both these regards, diffusion certainly appears consistent with competition goals.

However, as one descends from lofty principles and broadly defined objectives to practical implementation, tensions between the two bodies of law begin to emerge. These relate to the following:

1) Property rights. Specifically, whether a patent holders' right not to exploit a patent by undertaking production or by issuing a license is absolute, or can be hemmed in on the basis of competition principles?;

2) Exclusionary terms. Specifically ones right to include in licensing contracts restrictive clauses such as exclusivity terms, grant back requirements or, territorial restrictions.

3) Cooperative arrangements. Specifically The right to work together with others in joint research or cooperative exploitation of intellectual property.

\section{i/ Tensions between antitrust and intellectual property protection}

The main question from a competition policy perspective is whether the aforementioned forms of conduct should receive the same treatment when they are based on the exploitation of IP as when they involve the mere use of physical assets. In this regard, the bulk of the jurisprudence, both in the US and the European Union, shows that antitrust courts have been more lenient towards potentially abusive

\footnotetext{
${ }^{9}$ U.S. v. International Business Machines ( 69 Civ. 200, S.D.N.Y.)
} 
conduct involving the use of intellectual property (OECD, 1998). This is based, in part at least, on a desire not to inhibit innovation. ${ }^{10}$

However, the recent extension and/or strengthening of protection in areas such as software, databases, business methods and research tools has heightened fears that intellectual property law may now inhibit innovation instead of promoting it. The reason is that in several industries. it has become more costly to acquire know-how critical for entry. Also, the proliferation of new rights and the strengthening of protection in traditional areas seem to contribute to a proliferation of infringement suits. This and the generosity of awards to plaintiffs appear to many as a disincentive to engage in research that builds on protected knowledge. ${ }^{11}$. Economists have spoken of excess of protection (Gallini and Trebilcock 1998), patent thicket (Shapiro 2001) or digital boomerang (David 2001) as they articulated their apprehensions that recent IP legislation will adversely affect the pace of innovation.

Competition authorities have expressed a similar concern. The chairman of the US Federal Trade Commission has wondered publicly how many of the patents granted met minimal standards in terms of novelty, non-obviousness and utility; whether a 17year protection period was always warranted; how much legal action for infringement had merit based on fact (Pitofsky, 2000). He has also raised the question whether many patent applications were not filed simply to increase ones bargaining power visà-vis next generation innovators. Some of these issue are addressed in greater detail below.

\section{ii) Boundaries of the right to exclude}

IP laws do not obligate the holders of an intellectual asset to exploit it directly or to license others to so. The question whether such duty exists under competition law can be broken down as follows:

i) Under what conditions, if any, can direct exploitation of IP or licensing of IP be enjoined on the basis of antitrust principles? Should such conditions be identical to those applying to physical assets under the essential facilities doctrine?

ii) Does ones right not to exploit protected knowledge also imply a right not to supply a good produced with that knowledge under conditions where refusal to supply would otherwise trigger antitrust action?

iii) Should the application of antitrust rules in regard to discrimination among licensees of protected knowledge be identical to those applying to the sale of humdrum goods or services?

\footnotetext{
${ }^{10}$ Notable in this regard is adoption by antitrust authorities of a test under which a restrictive provision in a licensing contract should be allowed if it does not lessen competition more than disallowing the license.

${ }^{11}$ The United States took at the beginning of the 1980s a number of decisions designed to reinforce intellectual property rights both domestically and abroad. According to Hall and Ham (1999) "the 1982 formation of a centralised appellate court, the Court of Appeals for the Federal Circuit ushered in a "pro-patent" legal environment in the United States". Scotchmer (1999) claims that "this Court has upheld a much larger fraction of patent holders who complain of infringements than previous courts" See also Lerner (1995).
} 
Courts in the US and the EU have at times held that refusals to license a patent violate competition law. However, in neither jurisdiction, have they provided clear direction as to when a refusal to deal is anticompetitive where it involves intellectual property. The following cases illustrate the current state of affairs in the US.

1. In the Kodak case the Ninth Circuit Court of Appeals ruled that the defendant's refusal to license patented parts of its copiers to rival independent organizations was unlawful; The reason was anti-competitive intent. The Court held that a refusal to license would have been presumptively valid in the absence of evidence that the company's intent was to eliminate competitors e.g. if the sole purpose was to earn a larger return on its R\&D investment. However, another court reached a radically different conclusion in the later Xerox case, ruling that it is legal for a legitimate holder of a patent to refuse the issue a license regardless of intent or effect on competition ${ }^{12} 13$.

2. The second case relates to mergers and concerns divestitures and licensing as a means to preserve competition. Specifically, it addresses the question whether a consent order in a merger case could be made conditional on the divestiture of a research lab or the mandatory licensing of a key proprietary technology? The consent agreement entered into the Ciba-Geigy ${ }^{14}$ merger suggests that it can. The consent order stated that steps should be taken to maintain rivalry not only in the product market but also in the technology market and the innovation market ${ }^{15}$. The order provided for the licensing of a key proprietary technology as a condition of the merger. This was, based on the claim that without such licensing, competition in the technology market would be harmed. The essential facility doctrine was brought into play. It was argued that the specific gene therapy technology to which the parties held property rights was an essential input to nextgeneration developments. Under this doctrine, compulsory licensing could be used as a remedy under antitrust law.

3. Another case involves Intel, a firm that accounts for almost $80 \%$ of the world's supply of microprocessors. Because Intel and others control key patents on CPU technology, barriers to entry in the industry are high. They are heightened further by important network and feedback effects due to the combination of Intel chips with the Windows Microsoft's operating system (Wintel). In order to smoothen the incorporation of Intel's upcoming technologies into the complementary goods, Intel has implemented the practice of giving its main customers advance information about new and upcoming processor prototypes.

Intergraph, a producer of graphics workstations initiated the first case against Intel by suing the company and others for infringement on its CPU patents. Intel countered by removing Intergraph from the list of companies benefiting from

\footnotetext{
${ }^{12}$ CSU v Xerox Corp., In re Independent 203 F.3d 1322 (Fed. Cir. 2000)

${ }^{13}$ In reaction to this decision, Chairman Pitofsky of the Federal Trade Commission (Pitofsky, 2001) make public his concern that the Court's position gives a disproportionate weight to the regime of intellectual property protection in regard to the regime of antitrust.

${ }^{14}$ FTC File $961-0055$ (Dec. 1996)

${ }^{15}$ A technology market is one where intellectual property rights are transacted or licensed. An innovation market for a technology consists of the R\&D directed to new or improved goods or processes and the close substitutes (Gilbert and Sunshine 1995).
} 
advance notification of technical details about its forthcoming CPU's. What's more, the defendant threatened to discontinue the sale of microprocessors to the plaintiff if the latter carried on with its refusal to sell to it the patents it held on CPU technology. Intergraph won a preliminary injunction based on the argument that Intel's microprocessors and associated trade secrets were essential facilities under the antitrust laws. The court ordered Intel to deal with Intergraph under standard terms ${ }^{16}$. The apparent implication was that the essential facility doctrine, developed mainly to regulate access to essential physical equipment, applies to intangible assets.

However Intel appealed and won. The Federal Circuit Court held that Intel's refusal contravened neither antitrust nor patent laws. The Court held that two conditions required to make Intel's conduct unlawful were not met. First, Intel's microchips were not an essential input because other suppliers (AMD, Motorola, Sun, and IBM) were able to sell close substitutes. Second, the goal pursued by Intel's in refusing to sell was not to create a monopoly in the downstream market because the firm had no intention of entering into downstream activities.

Shortly before that decision was rendered the Federal Trade Commission (FTC) had filed a complaint against Intel in which it argued that the relevant market in which Intel behaved abusively was the innovation market. The FTC claimed that the probable effect of Intel's conduct was to weaken incentives of Intergraph and other manufacturers of CPU technology to innovate. This case was settled by a consent agreement ${ }^{17}$ under which Intel committed not to deny advance notification of technical information to any customer for the sole reason that such customer disputed Intel's ownership of IPR.

The different approaches taken by the FTC and the higher courts provide further illustration of the tension between antitrust and IP laws. The charge brought by the FTC and the settlement suggest a possible third test. A refusal to supply information or to sell patented products can be unlawful if it harms potential competition in an innovation market ${ }^{18}$. It is not sure whether this test is accepted by the Court of Appeals.

In summary one could say that US jurisprudence suggests the relevance of three criteria in regard to a refusal to license intellectual property: 1) the intent of the party refusing to issue a license, 2) the "essentiality" of the input embodying the knowhow; 3) the impact on incentives to innovate. At this stage though, clarity is still missing. This appears to be true in the EU as well (see Landolt and Ysewyn, 2001).

\footnotetext{
${ }^{16}$ See Baker (1999).

17 See FTC Dockett 9288: Agreement containing consent order, in the matter of Intel Corporation (http://www.ftc.gov/os/1999/9903/d09288intelagreement.htm)

18 Shapiro (2001) disagrees with this analysis, claiming that the FTC's approach brushed aside concerns about the hold-up to which Intel was subject. "Intel's true rivals in microprocessor design and manufacturing where either not subject to the conduct at issue since they where not Intel customers or had cross-licenses with Intel under which the litigation triggering these episodes would simply not occur in the first place". Shapiro claims that the initial sue of Intergraph against Intel was mostly a manifestation of an opportunistic behavior of a customer, motivated by putting some burden on the microprocessor's leader in order to obtain some ex-post royalties.
} 


\section{IP protection and cumulative innovation}

The traditional view that stronger protection promotes innovation has recently come under attack both by the business community ${ }^{19}$ and by economists in academia (Scotchmer, 1999, Shapiro, 2001). They have offered an alternative view grounded in the perception that technological change is not as an isolated event a cumulative process where each innovation, is built on knowledge previously acquired and possibly patented by forerunners. This view holds that a current innovation benefits not only current inventors and consumers but also offers benefits to the future innovators who will build on the current innovation. Moreover, innovations are often complementary, in the sense that the overall probability that a particular goal is achieved within a given time increases with the number of research lines adopted by the different potential innovators. Cumulative and complementary innovation processes are readily apparent in industries as diverse as biotechnology, computer software, semiconductors, microprocessors, digital videodisks, video games and the Internet.

Under this perspective, the relevant question in regard to incentives must be amended to read: What incentives will stimulate the proper amount of pioneering research and, at the same time, promote the right amount of effort to build around and/or from the initial innovation?

\section{i/ The hold-up problem}

Scotchmer (1999) points out that "since an innovator may be both buyer and a seller of licenses, it is not obvious whether strengthening IP provides him with more gains in one capacity than losses in the other". Shapiro, (2001) argues that in a process of cumulative and complementary innovations, IP protection may produce a "patent thicket" i.e. an overlapping set of patents to which a manufacturer must obtain rights when introducing a new product. This burden exposes subsequent innovators to the danger of being held-up by multiple infringement suits. Shapiro claims that the "holdup problem is not a mere theoretical possibility and that both patent and antitrust policy makers should regard it as a problem of first order significance in the years ahead".

Hall and Ham (2001) investigate the hold-up potential in the semiconductors industry. This very innovative industry displays a striking paradox. It shows an increasing propensity to patent. At the same time, firms rely on secrecy, lead time, superior manufacturing and design capabilities rather than on patents as protective devices. Hall and Ham explain this "patent paradox" by arguing that the portfolios of patents amassed by firms are best viewed as "bargaining chips" that serve to lend credibility to threats that others will effectively be sued for infringement. They add, however,

\footnotetext{
19 There are some indices that show that the business community seems now to be in favour of a reduction of the patent rights. This can be illustrated by the position expressed by Jeff Bezos, the CEO of Amazon.com in an open letter: "I now believe it's possible that the current rules governing business method and software patents could end up harming all of us". In the same letter, he proposed to reduce the business method and software patent's length to 3 or 5 years, instead of the current 17 years.
} 
that the portfolios also serve to reduce the risk of being held up by other patent holders and to enhance ones capacity to negotiate better terms for access to technology developed elsewhere. ${ }^{20}$

This raises two questions: 1) Does the hold-up problem fall within the ambit of competition policy; 2) If so, what tools does competition policy have to deal with it?

One way out of the hold-up problem is suggested by Green and Scotchmer (1995) and Scotchmer (1999). Because the hold-up problem arises from innovators' weak bargaining power when suits are brought after $R \& D$ costs have been sunk, they suggest that parties engage in ex-ante agreement on the division of profits, i.e. agreements between a first generation innovator and a potential applicant for a derived improved product. The ex-ante agreement ensures that the second-generation innovation is produced whenever it adds to joint profit. ${ }^{21}$ It also makes certain that the first innovator does not capture for himself the overall incremental joint profit resulting from an agreement with a second-generation innovator. In doing so the exante agreement between a holder of an initial right and a subsequent user, reconciles the incentives of first and second generation innovators.

Unfortunately, such co-operation faces obstacles. It involves co-ordination costs. One of them is that the pioneering inventor may not know with whom he should coordinate. It also may raise antitrust concerns, because it creates the danger of eliminating or slowing the race for the next generation technology.

\section{ii/ Cooperative arrangements between IPR holders}

Under what circumstances, ex-ante agreements such as cross licenses, patent pools and, joint standard settings alleviate the hold-up problem?

A cross-license is an agreement among two or more firms where each of them is granted the right to use technologies patented by the other parties. The agreement applies either to patents already issued (ex-post agreement) or to prospective future patents (ex-ante agreement). A patent pool is an arrangement under which a group of patent holders exploits and licenses, as a bundle, all the patents the members hold. Joint standard setting involves an agreement whereby a group of firms adopts the same technological standard. It ensures compatibility between their components and requires that members agree to license all patents essential to the standard. A joint standard may be implemented by a standard-setting organization or by the members of the industry. A joint standard is different from a de facto standard, which emerges when a single firm imposes its product or technology to the entire industry. All these arrangements may, but need not, raise antitrust concerns.

\footnotetext{
20 The hold-up risk explains why the Antitrust Guidelines for the Licensing of Intellectual Property Rights (1995) introduced quite severe rules against non-objectively based infringement allegations.

${ }^{21}$ The ex ante agreement in Green and Scotchmer (1995) is based on the Nash bargaining solution, the status-quo point being the net profit of each player before the investment for the second generation innovation is incurred. The retained framework is for quality improvement by successive innovations. The extent of patent protection is measured by the improvement gap below which an innovation infringes the previous one
} 


\section{Patent pools}

A patent pooling agreement is justified from a welfare point of view when the knowledge embodied in different patents pertains to complementary inputs into a specific technology. If so, pooling allows the internalization of the externality that results from complementary inputs. For the participating patent holders, it may be more profitable to set the price of the bundle lower than the sum of prices at which each patent would be offered by independent operators. This is merely an application to intellectual property of Cournot's well-known result that independent pricing of complementary inputs yields higher input prices and lower profits that under interdependent pricing. As such, a pooling of complementary patents should not raise serious antitrust concerns. Not only does it contribute to solve the hold-up problem, it also solves the externality problem.

However, a pooling of rival patents that combine competitive technologies may serve to reduce incentives to compete, in $\mathrm{R} \& \mathrm{D}$, in technology or in downstream product markets. Therefore it remains a matter of concern for antitrust.

\section{Cross-licensing}

The hold-up problem can also be solved by a cross licensing agreement between horizontal competitors when each participating firm holds patents to technology that the other firms need. Cross licenses are often found in the microprocessor industry where they are used by firms that want to avoid blocking positions among themselves.

Such agreements do not affect price competition in the product market when licensing fees do not depend on output (Katz and Shapiro, 1995). Some antitrust concerns may nevertheless arise, e.g. when cross licensing agreements include various field-of-use or geographic restrictions. Moreover, a grant of licenses to future patents may lower incentives to innovate because each party gains easier access to the technology owned by the other party.

The US Antitrust Guidelines for the Licensing of Intellectual Property recognize that cross-licensing and pooling arrangements may provide "pro-competitive benefits by integrating complementary technologies, reducing transaction costs, clearing blocking positions, and avoiding costly infringement costs". However, the Guidelines make it abundantly clear that these arrangements can be challenged under the rule of reason although they ae they are presumed to be pro-competitive. They make a clear distinction between patents that are complementary or essential for the specific technology and patents that are substitute or rival for the same technology.

They also establish that a proposed patent pool must be notified to the authorities. The notifying party must produce a publicized search under the supervision of an independent patent expert, familiar with the technology, who defines what the essential patents are for the corresponding technology. Second, the antitrust authority examines diverse aspects such as: the relationship of the IPR being combined; the nature of the markets in which those IP rights compete; the extent to which the pool controls access to these rights; and the extent to which the pool controls the terms on which future innovations will reach the market (Klein, 1997). 
In regard to the question whether the pooling agreement should be open to all firms who would like to join it, the Guidelines take the view that exclusion is unlikely to have anti-competitive effects, unless the following conditions hold:"(1) excluded firms cannot effectively compete in the relevant market for the good incorporating the licensed technologies and, (2) the pool participants collectively possess market power in the relevant market".

When these conditions are met, patent pools will be approved because they appear as being both pro-competitive and promoting innovation. This was the case for MPEG-2, a patent pool in the video compressing technology ${ }^{22}$. Patent pools will not be approved when they raise the concern that competition in the technology market or in the innovation market is lowered.

\section{Joint standard setting}

The antitrust concerns raised by joint standard setting are more complex although their effects are mostly pro-competitive, particularly in the presence of network effects. The Guidelines recognize that technological standards lower transaction costs and facilitate the acceptance of new products by consumers. Moreover, because technological compatibility increases the benefits of network externalities, the standard increases the demand for goods that are complementary to the standardized technology. Furthermore, a joint standard forestalls the emergence of a de facto standard.

A case in point is the agreement that led to implementation of the standard digital videodisk design $^{23}$. It was drawn up by computer producers, consumer electronics manufacturers and movie studios. In that case the FTC concluded that the standard enhanced welfare in two ways. By increasing the probability of consumer acceptance, it lowered the commercial risk involved in setting up production facilities of videodisks. And, in so doing, it was likely to induce more entry into the industry. Second, the commercial development of videodisks was likely to expand the demand for complementary products such as high-resolution displays. Therefore, the FTC concluded that the standard favoured both the cumulative process of innovation and the competitive process in the product markets.

However, it is important to keep in mind that joint standard setting may also have anti-competitive effects. First, there is a risk that one team member will convert an initially open standard into a de facto proprietary standard that he dominates ${ }^{24}$.

\footnotetext{
${ }^{22}$ An example of approved patent pool is related to the Video Technology Standard used in Electronics and Broadcast Industries, known as MPEG-2 video compressing technology. Nine owners of essential patents in this technology decided to pool their patents. They are: Columbia University, Fujitsu, General Instrument, Lucent Technologies, Matsushita, Mitsubishi, Philips, Scientific Atlanta, and Sony. The single license under the one-stop-shopping of a unique agent (MPEG LA) is available to those who provide products or services that store or transmit video information including televisions, digital video disks and players, telecommunications equipment as well as cable, satellite and broadcast television services.

(See http://www.usdoj.gov/atr/public/press_releases/1997/1173.htm)

${ }^{23}$ See Gates, S. (1998), "Standards, innovation and antitrust: Integrating innovation concerns in the analysis of collaborative standard setting", http://www.law.emory.edu/ELJ/volumes/spg98/gates.html ${ }^{24}$ For instance, the same consortium who participated to the standard digital videodisk tried also to agree for the digital versatile disk which corresponds to the next generation digital information device.
} 
Second, the standard may be used for collusive purposes. Third, there is a risk that by maintaining the industry locked-in, the standard will slow down the race for the next technology. Notwithstanding these concerns it seems that US antitrust procedures focus more on the productive and allocative efficiency aspects rather than on the possibly damaging dynamic effects on innovation which are much more difficult to evaluate.

\section{Conclusion: A role for competition policy in the design of intellectual property rights?}

One focus in this paper has been on the question whether competition policy can restrict uses of intellectual property rights that harm the competitive process. However, by restraining the role of competition policy in such way, we ignore another possible role that competition policy can play in shaping the pace of innovation.

Competition policy could provide refine incentives for research and innovation by fine tuning IP laws, particularly, where there is evidence that protection is overly broad and stifles competition (Gallini and Trebilcock, 1998). Such view also seems shared by Pitovsky (2001). Fisher and Rubinfeld (2000) opine that "the fact that innovation can bring consumer benefits should not provide a license for innovative firms to engage in anti-competitive acts".

Buigues et al.,(1995) hold that exploiting in the best way the complementarity between antitrust and IP makes it possible to correct each other's deficiencies, facilitate their enforcement and increase institutional credibility.

We agree with these statements. What we have tried to show in this paper is how the assessment of what constitutes an anti-competitive act is a difficult task in innovative industries. This is why meeting a coordination between competition policy and intellectual protection raises thorny problems. Nevertheless, public authorities should be very concerned by this coordination because coherence between microeconomic policies is a very important matter. We have illustrated some problems which arise when either regime, intellectual protection and antitrust, is accorded disproportionate weight.

A theoretical framework that can be of some help in investigating the question of how to enforce complementarity between antitrust and IP can be found in the literature that investigates the institutional design of regulatory mechanisms. One of the questions addressed by this literature deals with the justification of the separation between regulatory agencies. Those who argue for the separation of regulators. do so for two reasons. First, because a separation acts as a commitment against the threat of regulatory captures (Laffont and Martimort, 1998). Second, because the presumption that some private welfare improving action (e.g. a decision by a firm to file a patent) could be deterred if it involves the risk of triggering antitrust action under a common regulatory framework (Bensaid et al., 1995). One could add that separation between

Some members have agreed to an encryption standard that will help protect copyrighted works, but the fear that one or a small number of firms would dominate such standard did not allow an agreement. 
antitrust and IP regulators also has merit because it maintains the comparative advantages of the two legal institutions.

One claim is that complementarity between intellectual protection and competition policy could be improved if antitrust authorities provided input into the legislative process. Competition policy could affect both the ex-ante incentives to innovate, by ensuring that innovation receives a justified return on her R\&D investments and, the nature of post innovation competition in the product market. In turn, IP authorities would allocate rights by designing rules that favour incentives to innovate without conflicting with antitrust principles. This interaction would have the advantage of reminding each authority that neither antitrust nor intellectual property protection are ends by themselves, but only complementary instruments for allocating resources which both promote dynamic efficiency especially in innovative industries (d'Aspremont et al. 2000). For instance, competition policy and intellectual protection should both try to clarify the conditions where inappropriate protection (either excessive or insufficient) may be detrimental both for competition and for innovation.

One way to converge towards coordination could be by encouraging antitrust and IP authorities to issue common guidelines accepted by both sides. This would generalize the current attempts by antitrust agencies to define the "safety zones", i.e. the type of collaborative arrangements which are immune to antitrust scrutiny.

Some rules have been suggested. One of them is that the instruments of patent protection (length, scope, etc.) need not be uniform across industries. A case in point concerns the industries where network effects are important, for instance the software industry. Starting from the argument that strong intellectual property rights and network externalities reinforce each other by favouring market dominance by a single firm, Church and Ware (1998) argue in favor of weaker protection in these industries. For instance, excessive intellectual property protection creates a burden in software markets since it is more and more difficult to build around previous patented software. Patenting does not seem to be the best form of protection, nor the best incentive to innovate in these markets. In a dynamic world, software imitation can provide benefits to the innovator and to society as a whole (Bessen and Maskin, 2000). For these reasons, a current proposal calls for the creation of sui generis protection in software that would combine copyright and compulsory licensing after a relatively short period. A discussion on the merits and drawbacks of such proposal is beyond the scope of this paper.

\section{REFERENCES}

AGHION, P., N. BLOOM, R. BLUNDELL, R. GRIFFITH and P. HOWITT (2001), "Empirical estimates of the relationship between product market competition and innovation", mimeo, University College London

AGHION, P., C. HARRIS, P. HOWITT and J. VICKERS (2001), "Competition, imitation and growth with step-by-step innovation", Review of Economic Studies, 68, 467-492

AGHION, P., C. HARRIS, and J. VICKERS (1997), "Competition and growth with step-by-step innovation: an example", European Economic Review, 41, $771-782$ 
AGHION, P. and P. HOWITT (1992), "A model of growth through creative destruction", Econometrica, 60, 323-351

AREEDA, P. and D. TURNER (1975), "Predatory pricing and related practices under section 2 of the Sherman Act", Harvard Law Review, vol. 89, 891-900

ARROW, K. (1962), "Economic welfare and the allocation of resources for invention", in Nelson, R.(Ed.), The Rate and Direction of Incentive Activity: Economic and Social Factors, Princeton University Press

d'ASPREMONT, C., D. ENCAOUA and J.P. PONSSARD (2000), "Competition policy and game theory: Reflection based on the cement industry case", in J. Thisse and V. Norman, (Eds.), Competition Policy and Market Structure: Game Theoretic Approaches, Cambridge University Press, Cambridge

AUDRETSCH, D.B., W.J. BAUMOL and A.E. BURKE (2001), "Competition policy in dynamic markets", International Journal of Industrial Organization, 19, 5, 613-634

BENSAID, B., D. ENCAOUA and A. PERROT (1995), "Separating regulators to reduce risks due to overlapping control", mimeo, Université de Paris I

BESSEN, J. and E. MASKIN (2000), "Sequential innovation, patents and imitation", MIT, WP 00-01

BOONE, J. (2001), "Intensity of competition and the incentive to innovate", International Journal of Industrial Organization, 19, 5, 705-726

BOONE, J. (2000), "Competitive pressure: the effects on investments in product and process innovation", RAND Journal of Economics, 31, 3, 549-569

BUDD, C., C. HARRIS and J. VICKERS (1993), "A model of the evolution of duopoly: does the asymmetry between firms tend to increase or decrease?", Review of Economic Studies, 60, 543-573

BRESNAHAN, T. (1999), "New modes of competition: implications for the future structure of the computer industry"" in J. Eisenach and T. Lenard (Eds.) Competition, Innovation and the Microsoft Monopoly: Antitrust in the Digital Marketplace, The Progress and Freedom Foundation, Kluwer Academic Publishers, Boston

BUIGUES, P., A. JACQUEMIN and A. SAPIR (1995), "Complementarities and conflicts in EC microeconomic policies" in P. Buigues, A. Jacquemin and A. Sapir, (Eds.) European Policies on Competition, Trade and Industry, Edward Elgar, Adelshot, UK-Brookfield, US

CABALLERO, R., and A. JAFFE (1993), "How high are the giants shoulders? An empirical assessment of knowledge spillovers and creative destruction in a model of economic growth", NBER Macroeconomic Annual, 15-74

CHURCH, J. and R. WARE (1998), "Network industries, intellectual property rights and competition policy" in R. Anderson and N. Gallini, Eds. Competition Policy and Intellectual Property Rights in the Knowledge Based Economy, Calgary, University of Calgary Press for the Industry Canada Research

DAVID, P. (2000), “The Digital Technology Boomerang: New Intellectual Property Rights Threaten Global "Open Science", forthcoming in the World Bank Conference Volume: ABCDE-2000

EISENACH, J. and T. LENARD eds. (1999), Competition, Innovation and the Microsoft Monopoly: Antitrust in the Digital Marketplace, The Progress and Freedom Foundation, Kluwer Academic Publishers, Boston

ENCAOUA, D. and D. ULPH (2000), "Catching-up or leapfrogging? The effects of competition on innovation and growth", EUREQua W.P. 2000.97, Université Paris I 
EVANS, D., F. FISHER, D. RUBINFELD and R. SCHMALENSEE (2000), Did Microsoft Harm Consumers? Two Opposing Views, AEI-Brookings Joint Center for Regulatory Studies, Washington, D.C.

EVANS, D., A. NICHOLS and R. SCHMALENSEE, (2001), "An Analysis of the Government's Economics Case in U.S. versus Microsoft", Antitrust Bulletin, forthcoming

FARREL, J. and M. KATZ (2001), "Competition or predation? Schumpeterian rivalry in network markets", University of California, Berkeley, Department of economics, WP E01-306

GALLINI, N. and M. TREBILCOCK (1998), "Intellectual Property Rights and Competition Policy, A Framework for Analysis of Economic and Legal Issues", in OECD Competition Policy and intellectual Property Rights, Series Roundtables on Competition Policy, 18

GILBERT, R. and S. SUNSHINE (1995), "Incorporating dynamic efficiency concerns in merger analysis: The use of innovation markets", Antitrust law Journal, 63, 569-601

GREEN, J. and S. SCOTCHMER (1995), "On the division of profit in sequential innovation", RAND journal of Economics, 26, 1, 20-33

HALL, B. and R. HAM (2001), "The patent paradox revisited: An empirical study of patenting in the US Semiconductor Industry", Rand Journal of Economics,

KATZ, M. and C. SHAPIRO (1999), "Antitrust in software markets", in J. Eisenach and T. Lenard (Eds.), Competition, Innovation and the Microsoft monopoly: Antitrust in the digital marketplace,. The Progress and Freedom Foundation, Kluwer Academic Publishers, Boston

KATZ, M. and C. SHAPIRO (1995), "On the licensing of innovations", RAND Journal of Economics, 16, 4, 504-520

KLEIN, J. (1997), "Cross licensing and antitrust law", Address before the American Intellectual Property Law Association, San Antonio, Texas

LAFFONT, J.J. and D. MARTIMORT (1998), "Collusion and Delegation", The Rand Journal of Economics, 29, 280-305

LANDOLT, P. and YSEWYN (2001), "Intellectual Property Rights and EC Competition Law", @opyright World, June/July, 19-21

LERNER, J. (1995), "Patenting in the shadow of competitors", Journal of Law and Economics, October, 463-495

McGEE, J. (1958), "Predatory price cutting: The Standard Oil (N.J.) Case", Journal of Law and Economics, vol. 1, 137-169

OECD (1998), Competition Policy and intellectual Property Rights, Series Roundtables on Competition Policy, 18

ORDOVER, J. and R. WILLIG (1981), An Economic Definition of Predation: Pricing and Product Innovation, Yale Law Journal, vol. 91, 8-53

PITOFSKY, R. (2001), "Antitrust and intellectual property: unresolved issues at the heart of the new economy", prepared for the Antitrust, Technology and Intellectual Property Conference, Berkeley Center for Law and Technology, University of California, Berkeley

PITOFSKY, R. (2000), "Challenges of the New Economy: Issues at the intersection of Antitrust and Intellectual Property", Conference of the American Antitrust Institute: An Agenda for Antitrust in the $21^{\text {st }}$ Century, National Press Club, Washington

PITTMAN, R. S. (1984), "Predatory investment: US v. IBM, International Journal of Industrial Organization, 341-365 
POSNER, R. (2001), "Antitrust in the new economy", University of Chicago, Olin Working Paper $\mathrm{N}^{\circ} 106$

RUBINFELD, D. (1998), "Competition, innovation and antitrust enforcement in dynamic network industries", Spring Symposium of Software Publishers Association, San Jose, California

SCOTCHMER, S. (1999), "Cumulative innovation in theory and practice",. University of California, Berkeley

SHAPIRO, C. (2001), "Navigating the patent thicket: cross licenses, patent pools and standard setting", forthcoming, Innovation Policy and the Economy, Eds. A. Jaffe, J. Lerner, and S. Stern, MIT Press

VALENTINE, D. (1999), "Abuse of dominance in relation to intellectual property: US perspectives and the Intel cases", The Israel International Antitrust Conference, Tel Aviv

VICKERS, J. (1986), "The evolution of industry structure when there is a sequence of innovations", Journal of Industrial Economics, 35, 1-12 